\title{
Exchange Rate Volatility, Stock Prices Movement and Aggregate Output in Nigeria
}

\author{
Julius Olakunle Adeoti \\ Department of Economics, \\ Emmanuel Alayande College of Education, Oyo, Nigeria \\ Dauda Gbolagade Adebisi \\ Department of Accounting and Finance, \\ Bowen University, Iwo, Nigeria
}

\begin{abstract}
The paper examined the causal relationship among exchange rate volatility, stock prices movement and aggregate output in Nigeria from 1986 to 2014 . The study used ARDL Bound test cointegration approach to establish long run relationship and Vector Error Correction Model (VECM) to examine the short and long run causal relationship among the variables. The results showed that there was long run relationship among exchange rates volatility, stock prices movement and real GDP. Furthermore, a unidirectional causality was observed between aggregate output and stock prices movement in the short run, while in the long run, a bi-directional causal relationship was established. However, the study could not detect, either in the short or long run, any causality from exchange rate volatility to either stock prices movement or real GDP and vice versa. In this regard, more efforts should be geared towards financial market development, while less attention should not be paid to exchange rates stability.
\end{abstract}

Keywords: aggregate output, ARDL, causality, exchange rate volatility

\section{INTRODUCTION}

Stability of foreign exchange rates is indispensable for the healthy macroeconomic performance of an economy (Kim and Singal, 2000; OECD, 2002; Kolawole and Olalekan, 2013). Its volatility is, however, disruptive to the growth of developing economies, like Nigeria, by imposing real economic costs on international trade and productive investment in the countries, thus encouraging protectionism and complicating the setting of monetary policy for these economies (Chetwin, Ng and Steenkamp, 2013).

Exchange rates volatility is the risk associated with the impulsive movements in the exchange rate of a particular country. It is a measure of the level of randomness of the exchange rate at any particular time. Exchange rate is said to be volatile when its series change rapidly from period to period in an unpredictable manner. A long or short period fluctuation in exchange rate sturdily affect the growth performance of open economies through trade mechanism, liquidity and wealth effect (Gunther, 2007; Qayyum and Khan, 2012; Mayowa 2013). More specifically, exchange rates swings exert strong influence on the current account position of a country with real economic costs that affect foreign investments (direct and portfolio), price stability, firm profitability and general economic performance. Such unpredictable changes play significant role in investment and confidence position of investors (Kolawole and Olalekan, 2013; Mayowa, 2013). 
Basically, there are two main schools of thought on analysis of the direction of causality between exchange rate volatility and stock prices movement. Although, the two schools have posed contradicting conclusions. The first approach was proposed by Dornbusch and Fisher (1980) with the 'flow oriented' models of exchange rates. The analysis centres specifically on the way exchange rate fluctuations influence the output of firms and their competiveness in domestic and international markets. The approach is of the view that if firms are more competitive, it will have an unswerving positive effect on its stock prices. This is due to the fact that stock prices represent future cash flow stream for the firms. Hence, flow oriented model postulates that fluctuations in the exchange rates cause movement in stock prices.

The second approach known as the 'stock oriented' model was proposed by Frankel (1983) and developed by Branson (1993). The approach states that advances in the stock market affect exchange rate through liquidity and wealth effects. The school holds that a decrease in stock prices of firms reduce the wealth of local investors, which lowers their demand for money. Conversely, a rise in the domestic stock prices would attract capital flows, which increases the demand for domestic currency and cause exchange rate to appreciate. Hence, the movement in stock prices evolves volatility in the exchange rates. Empirical evidence of either flow or stock theories abound in the literature with varying results depending on the economies studied, period investigated or techniques employed.

Exchange rate volatility has become a great concern in Nigerian economy after the introduction of the Structural Adjustment Programme (SAP) in 1986. A major component of SAP was the adoption of floating exchange rate policy. The uncertainty associated with the policy, however, aggravated the volatility in the value of the Naira, increased the stochastic behaviour of exchange rate in the country and consequently the total output of the economy (Olanipekun, 2013). Furthermore, the development has had tremendous impacts on stock market movement in Nigeria, one of which is the exposure of investors and local firms to financial risks (Okpara and Odinonye, 2012; Zubair, 2013).

Different studies have empirically investigated either flows or stock theory to analyse the causal relationship between exchange rate and stock prices movement in Nigeria. A common feature of those studies is the emphasis on the analysis of causality either between exchange rates volatility and stock prices, stock prices movement and economic growth, exchange rates variations and economic growth with little attention on the three variables combined together. This study, however, differs by analysing causality among exchange rates volatility, stock prices movement and aggregate output in Nigeria. To our best of knowledge, in Nigeria, no study has attempted to study causality among these variables mentioned. By extension, more attention was paid to the period i.e. short run or long run when causality occurred among the variables. The period in which the causality occurs was important so that it would guide the policy makers on whether short term or long term policy should be formulated. This section is followed by literature review, next is the methodology, followed by results and discussion and lastly the conclusion.

\section{LITERATURE REVIEW}

There is a great deal of empirical literature on causality either between foreign exchange rate volatility and stock prices movement, foreign exchange rate volatility and economic growth or stock prices movement and economic growth for different economies. Phylaktis and Ravazzolo (2005) studied dynamics between stock prices and exchange rate and the mechanism through which exogenous shocks were discovered to have affected stock markets in Hong Kong, Malaysia, Singapore, Thailand and Philippines. Multivariate granger causality test was employed and the results revealed that stock and foreign exchange markets were positively 
related. Kurihara (2006) examined the relationship between exchange rate and stock prices during quantitative easing policy in Japan. The study used OLS technique and found that exchange rate had predictive information on Japanese Stock Prices.

Similarly, Morales (2007) investigated the dynamic relation between exchange rate and stock prices from Czech Republic, Hungary, Poland and Slovakia, using Vector Error Correction Modelling and granger causality techniques. The results showed no evidence of the variables moving together either in the long run or in the short run for other countries except for Slovakia. Also, the study found a uni-directional causality running from exchange rate to stock prices in Hungary, Poland and Czech Republic. Expanding Morales (2007) by including more countries, Islami (2008) analyzed the correlation between foreign exchange market and stock market in Ireland, Portugal, Spain, Greece, Poland, Czech Republic, Slovenia and Hungary. Using monthly data, the study employed OLS and VAR method to analyse the variables. The results showed that causality ran from stock market to the exchange rate in all the economies.

In another development, Alagidede, Panagiotidis and Zhang (2010) examined causality between stock prices and exchange rates in Australia, Canada, Japan, Switzerland and the UK from 1992:1 to 2006:12. Using both Hsiao's and non-parametric causality tests, the findings revealed that, though there was no long run relationship between stock prices and exchange rate, however, causality ran from exchange rate to stock prices in Canada, Switzerland and the UK. Karunanayake, Valadkhani and O'Brien (2012) assessed the interaction between stock market returns and GDP growth rates in four Anglo-Saxon economies that comprise the US, the UK, Canada and Australia from 1959 to 2010. The diagonal version of Engel and Kroner's (1995) BEKK model was used to verify the volatility spillovers within and across stock market returns and GDP growth rates. The study discovered that cross country means spillovers arising from stock market towards GDP growth or GDP growth towards stock return series were not statistically significant across any of the countries.

Also, Kumamoto and Kumamoto (2014) accessed the effect of the degree of currency substitution on nominal exchange rate volatility in Indonesia, the Philippines, Czech Republic, Hungary, Poland, Argentina and Peru. The study employed T-GARCH method and the result showed that the degree of currency substitution positively affected conditional variance of the depreciation rate of the nominal exchange rate in most of the sampled countries. Nazlioglu, Kar and Akel (2014) analysed the causality between exchange rate and stock prices in Bulgaria, Czech Republic, Estonia, Hungary, Latvia, Lithuania, Poland, Romania and Russia from 1995 to 2011. The study used Toda-Yamamoto approach and non-linear causality test. It found that no causal relationship existed between the variables in Bulgaria, Estonia, Latvia and Lithuania except in Russia.

In Nigeria, Yinusa and Akinlo (2008) examined the dynamic relationship among exchange rate volatility, currency substitution and monetary policy. The study employed VECM method and the results showed that exchange rate volatility and currency substitution responded to monetary policy only in the medium term. Ewah, Esang and Bassey (2009) appraised capital market efficiency on economic growth in Nigeria from 1961 to 2004. Using OLS method, the findings showed that there was a linkage between capital market efficiency and economic growth in Nigeria. Yaya and Shittu (2010) studied the influence of inflation and exchange rate on conditional stock market volatility in Nigeria. The study used ARCH and GARCH models introduced by Engel (1982) and expanded by Bollerslev (1986) on data set from 1991 to 2008. The study made it known that exchange rates lag and inflation rates exerted influence on conditional stock market volatility. 
Umoru and Asekoma (2013) examined the dynamic interaction between stock prices and exchange rate in Nigeria, using daily data from 2000 to 2012. Using SVAR model, the study discovered a bi-directional causal relationship between exchange rate movement and the stock prices. Oyinlola, Adeniyi and Omisakin (2014) investigated the long and short run dynamics of stock prices and exchange rates in Nigeria, using daily data set from January 2, 2002 to August 11,2011 . The study used E-GARCH model and the result revealed that there was a unidirectional causality from stock price to exchange rate. Okwuchukwu (2015) examined the effect of exchange rate volatility and stock market performance on the inflow of foreign direct investment to Nigeria, using data from 1980 to 2013. The results revealed that exchange rate volatility had negative effect on the inflow of foreign direct investment to Nigeria both in the long run and in the short run.

Salisu and Oloko (2015) studied the spillovers between stock market and foreign exchange market in Nigeria, using VARMA-AMGARCH models. The study found there was a persistent volatility spillovers from stock market to foreign exchange market, while evidence of negative returns spillover from stock market to foreign exchange abounds was discovered. Odili (2015) investigated the effect of exchange rates trend and volatility on imports in Nigeria from 1971 to 2011. Employing Parsimonious ECM model, the study found that exchange rate trends had effect on imports in the long run and causality ran from exchange rate volatility to imports in Nigeria.

\section{METHODOLOGY}

The endogenous Solow growth theory is used to derive the models for estimation in this study, given that after modification, it has inherent capability to incorporate aggregate output, exchange rate and stock market prices. The endogenous growth model could be specified as:

$$
Y_{t}=f\left(A K_{t}, L_{t}\right)
$$

Where $Y_{t}$ is aggregate output, $L_{t}$ is the stock of labour in the economy, $K_{t}$ is the stock of capital accumulation and A represents total factor productivity which is technology. In line with CudiTuncer and Alovsat (2001), exchange rates affects technology (A) by discouraging or spurring its importation, therefore, equation (1), is disintegrated to:

$$
A=f(\operatorname{Re} e r)
$$

Where Reer is real exchange rate.

Furthermore, $K_{t}$ i.e. capital in equation (1) can be decomposed into physical capital and human capital:

$$
K=f\left(K_{p}, K_{h}\right)
$$

Where $K_{p}$ is physical capital and $K_{h}$ is human capital

According to Demirgue-Kunt and Levine (1996), human capital is assumed to be constant, therefore equation (3) is written as:

$$
K=f\left(K_{p}\right)
$$

Substituting equation (2) and (4) in equation (1),

$$
Y=f\left(\operatorname{Re} e r, L, K_{p}\right)
$$


Following Donwa and Odia (2010), the stock of physical capital and stock of labour are determined by the level of investment in the capital market of an economy, thus equation (5) can be expressed to capture the effect of exchange rates and stock prices movement on aggregate output. Equation (5) is therefore expressed as:

$$
G d p=f(\operatorname{Re} e r, A l s i)
$$

Where Alsi is All Share Index, proxy for stock prices movement. Using GARCH (p, q) to extract the volatility of real exchange rate and incorporating this into equation (6) to capture exchange rate risk, the model becomes

$$
G d p=f(h, A l s i)
$$

Where $h$ is exchange rate volatility

From equation (7), the specific equation for estimation is specified as

$$
G d p=+h+A l s i+
$$

To determine the existence of causality among exchange rate volatility, stock prices movement and aggregate output, we re-specified equation (8) in three sets of ARDL models, using first difference of the variables in an unrestricted error correction model of the form:

$$
\begin{aligned}
& G d p_{t}=+{ }_{1} G d p_{t} i^{+} 2_{t} h_{i}{ }_{3} A l s i_{t} i^{+}{ }_{j=1}^{n} 1 j G d p_{t} j^{+}{ }_{j=0}^{n} 1 j h_{t} j_{j=0}^{+}{ }_{j j}^{n} A l s i_{t} j^{+} t \\
& h_{t}=+{ }_{1} G d p_{t i}+2^{h_{t} i}+{ }_{3} A l s i_{t} i_{j=0}^{+}{ }_{j=0}^{n} G d p_{t} j_{j=1}^{+}{ }_{j j}^{n} h_{t} j_{j=0}^{+}{ }_{j j}^{n} A l s i_{t} j^{+} t
\end{aligned}
$$

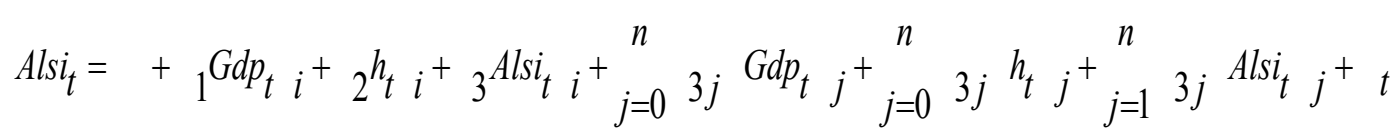

$\Delta$ represents first difference operator; $\varphi_{\mathrm{i}}, \eta_{\mathrm{i}}$, and $\Theta_{\mathrm{i}}$, are long run multipliers; $\kappa_{\mathrm{i}}, \beta_{\mathrm{i}}$, and $\chi_{\mathrm{i}}$ are examples of short-run dynamic coefficients; $\mu_{\mathrm{t}}$ are white noise errors; $\alpha, \delta$, and $\partial$ are drift terms; $n$ is the lag length chosen optimally for each of the variables using Akaike Information Criterion (AIC) and Schwarz Information Criteria (SIC).

\section{Unit Root Test}

\section{RESULTS AND DISCUSSION}

Table 1 presents the results of Augmented Dickey Fuller (ADF) and Phillip Perron (PP) unit root tests. The ADF results show that stock prices movement (Alsi) is stationary at level, while the other two variables i.e. real gross domestic product (Gdp) and exchange rate volatility (h) are first difference i.e. I(1) process. However, PP results reveal that all the three variables are first difference at $1 \%$ and $5 \%$ level of significance. The results of ADF indicate that all the 
Table 1. Results of Unit Root Tests

\begin{tabular}{lllll}
\hline Variable & & ADF & & PP \\
\hline & Level & First Diff. & Level & First Diff. \\
Alsi & $-3.532788^{*}$ & & -1.329704 & $-6.213472^{*}$ \\
Gdp & -0.950592 & $-.3 .3129^{* *}$ & 0.514163 & $-3.0462^{* *}$ \\
h & -1.209775 & $-9.705405^{*}$ & -1.222466 & $-9.705908^{*}$ \\
\hline
\end{tabular}

variables are integrated of different order. We therefore conclude that all the three variables are stationary at different order. In this case, Autoregressive Distributed Lag (ARDL) Bound Test of cointegration is applicable to establish the long run relationship among the variable. In order to estimate ARDL model, it is appropriate to determine the optimal lag length to be used. It is evident that various lag length selection criterion produced conflicting results. Therefore, the selection of lag length is based on the outcome of Akaike Information Criteria (AIC) and Schwarz Information Criteria (SIC) respectively, choosing lag 6.

\section{Cointegration}

Tables 2 presents the ARDL cointegration results. From Table 2, the results reveal that there are two cointegrating equations in the models, given the statistical significance of F-statistics and the probability values calculated from Wald coefficient restriction test. The calculated Fstatistic values are compared with the critical values at $1 \%, 5 \%$ and $10 \%$ respectively as suggested by Pesaran, Shin and Smith (2001).

Table 2. ARDL Cointegration Results

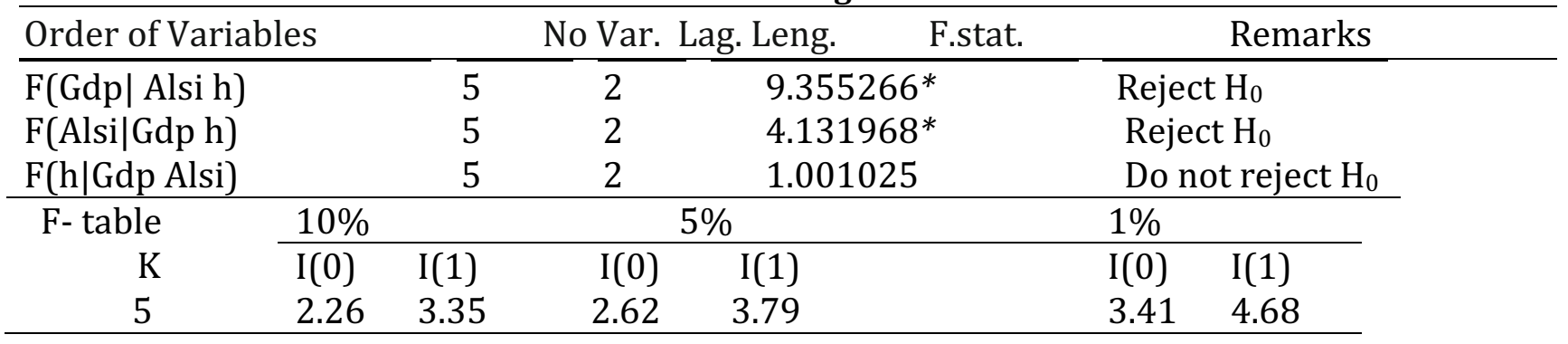

The values of computed F-statistics for three equations involving each variable as dependent variable are (9.355266), (4.131968) and (1.001025) respectively. Since two of the calculated F.statistic values fall above the table values at $5 \%$ and $10 \%$ respectively, in this case, we therefore conclude that there is long run relationship among exchange rate volatility, stock prices movement and total output in Nigeria.

In order to examine the causality among exchange rate volatility, stock prices movement and total output series, we performe the null hypothesis test of no causality within the Vector Error Correction Model (VECM) framework as shown in Table 3 and 4. In this case, we divide the period in which the causality occurred in to two i.e. long run and short run. 
Table 3. Result of VECM Short Run Causality Test

\begin{tabular}{llll}
\hline & \multicolumn{3}{c}{ Short run Causality } \\
\hline Dept var. & Gdp & Alsi & h \\
Gdp & & $14.81072^{*}$ & 0.401857 \\
& & $(0.0218)$ & $(0.9988)$ \\
Alsi & 5.901825 & - & 0.164888 \\
& $(0.4343)$ & & $(0.9999)$ \\
H & 0.871837 & 0.360642 & - \\
& $(0.9900)$ & $(0.9991)$ & \\
\hline
\end{tabular}

Note: ${ }^{* * *},{ }^{* *}$, and ${ }^{*}$ show level of significance at $1 \%, 5 \%$ and $10 \%$.

Probability values in parentheses.

Table 4. Result of VECM Long Run Causality Test

\begin{tabular}{lccc}
\hline \multicolumn{3}{c}{ Long Run Causality } \\
\hline $\mathrm{ECT}_{\mathrm{t}-1}$ & $\mathrm{t}-$ statistics & $5 \%$ & $1 \%$ \\
$\mathrm{Gdp}$ & $-3.63744^{*}$ & 1.66 & 2.36 \\
Alsi & $3.025625^{*}$ & 1.66 & 2.36 \\
$\mathrm{H}$ & -0.23349 & 1.66 & 2.36 \\
\hline
\end{tabular}

Note: * indicates level of significance at $1 \%$

In the short run, with $\left({ }^{2}=14.8107 ; \mathrm{p}<0.05\right)$, the results show the presence of unidirectional causality running from Gdp to all share index (Alsi) at 5\% level of significance. It is therefore concluded that there is a unidirectional causal relationship running from aggregate output to stock price movement in Nigeria. The implication is that changes in the level of aggregate output has predictive information on movement of stock prices in Nigeria in the short run. Hence, any increase in aggregate output only contributed to movement of stock prices and did not give any information about whether or not exchange rate would be volatile.

On the other hand, the probability value of the stock price movement is insignificant at 0.4343 when its coefficient value is restricted. This show that causality does not run from stock price movement to aggregate output in Nigeria in the short run. The coefficient of exchange rate volatility (h) also show insignificant statistics $\left({ }^{2}=0.8718 ; \mathrm{p}>0.05\right)$ and $(0.9991)\left({ }^{2}=0.3606\right.$; $\mathrm{p}>0.05$ ) when tested against aggregate output and stock price movement respectively. The development indicates that there is no causal relationship running from exchange rate volatility to either aggregate output or stock price movement in Nigeria.

From Table 4, the results show that in the long run, there is an evidence of a bi-directional causal relationship between aggregate output and stock price movement in Nigeria. This implies that stock price movement has statistically significant predictive influence on aggregate output in the economy of Nigeria. Similarly, aggregate output has statistically significant predictive influence on stock price movement in Nigeria. These developments are revealed by the coefficients of the t-statistics, which show aggregate output with $(-3.63744)$ and stock price movement with (3.025625), both values are statistically significant at $1 \%$ level and are greater than $t$-tabulated values of $(2.36)$ at $1 \%$ and 1.66 at $5 \%$ significant levels. Hence, in the long run, stock price movement granger cause aggregate output in Nigeria and aggregate output also granger cause stock price movement in Nigeria. These results are in contrast to the findings of Kolapo and Adaramola (2012), Umoru and Asekoma (2013), Lawal and Ijirshar (2015), but corroborating the results of Ikoku (2012), for Nigeria. \# 


\section{CONCLUSION}

It was observed that a great deal of empirical literature had investigated the causal relationship either between exchange rate volatility and stock prices movement, exchange rates volatility and economic output or stock prices movement and output growth over different period, using different techniques. It was however clear that attempt had not been made to combine these three variables together i.e. exchange rates volatility, stock prices movement and aggregate output simultaneously for analysis, hence this study. Therefore, the study examined the causality among exchange rates volatility, stock prices movement and aggregate output in Nigeria from 1986 to 2014.

Examination of causality among the variables revealed that in the short run, there was the presence of a unidirectional causal relationship running from aggregate output to stock price movement at 5\% level of significance. However, there was no causality between either exchange rate volatility and aggregate output or stock price movement in the short run in Nigeria. Similarly, in the long run, there was an evidence of a bi-directional causal relationship between aggregate output and stock price movement in Nigeria, showing that aggregate output granger caused stock price movement and stock price movement also granger caused aggregate output in Nigeria.

Based on these findings the study concluded that in the short run, there was a causal relationship between aggregate output and stock price movement and that causality ran from aggregate output to stock price movement. The short run, impact of the exchange rate volatility was statistically insignificant. In the long run, there was a bi-directional causal relationship between aggregate output and stock price movement in Nigeria. These results essentially showed that in the short run and long run, aggregate output was an effective determinant of stock price movement in Nigeria.

\section{References}

Akinlo, A.E. \& Adejumo, V.A. (2014). Exchange Rate Volatility and Non-Oil Exports in Nigeria: 1986-2008. International Journal of Business and Management. 9 (2).

Ariyo, A. \& Adelegan, O. (2005). Assessing the Impact of Capital Market Reforms in Nigeria: An Incremental Approach. Paper Presented at the 46th Annual Conference of the Nigerian Economic Society in Lagos.

Asaolu, T. 0. \& Ogunmuyiwa, M. S. (2011). An Econometric Analysis of the Impact of Macroeconomic Variables on Stock Market Movement in Nigeria. Asian Journal of Business Management. 3(1), 72-78

Babatunde, O.A. (2013). Stock Market Volatility and Economic Growth in Nigeria (1980-2010). International Review of Management and Business Research. 2(1), 201-209.

Bahmani-Oskooee, M. (2001). Nominal and Real Exchange Rates of Middle Eastern Countries and their Trade Performance. Applied Economics. 33(1), 103-111

Bollerslev, T. (1986). Generalized Autoregressive Conditional Heteroskedasticity. Journal of Econometrical, 307 327.

CBN, (2014). Central Bank of Nigeria Annual Publications.

Clark, P. Tamirisa, N. \& Wei, S. (2004). A New Look at Exchange Rate Volatility and Trade Flow, IMF Working Paper, No.235, (Washington DC)

Cudi-Turner, G. \& Alvosat, M. (2001). Stock Markets and Economic Growth: A Causality Test. Institute of Social Science, Istanbul Technical University.

Dell'Ariccia, G. (1999). Exchange Rates Fluctuation and Trade Flows: Evidence from the European Union. IMF Staff Papers. 46 (3), 31-34.

Demirgmoue-Kunt, A, \& Levine, R. (1996). Stock Market, Corporate Finance and Economic Growth: An Overview. The World Bank Review. 10 (2), 223-239. 
Donwa, P. \& Odia, J. (2010). An Empirical Analysis of the Impact of the Nigerian Capital Market on Her Socioeconomic Development. Journal of Social Sciences, 24 (2), 135-142.

Ewah, S.O.E., Esang, A.E. \& Bassey, J.U. (2009). Appraisal of Capital Market Efficiency on Economic Growth in Nigeria. International Journal of Business and Management. 4 (12), 219 - 228.

Granger, C.W.J., Huang, B. \& Yang, C. (2000). A Bivariate Causality between Stock Prices and Exchange Rates. The Quarterly Review of Economics and Finance. 40,337-354

Gunther, S. (2007). Exchange Rate Volatility and Growth in Small Open Economies of the EMU Periphery. European Central Bank Working Paper Series. No 773.

Ikoku, A.E. (2012). Is the Stock Market a leading Indicator of Economic Activity in Nigeria? Journal of Applied Statistics. 1(1), 17-38.

Kandilov, I. T. (2007). The Effects of Exchange Rate Volatility on Agricultural Trade. American Journal of Agricultural Economics, 90, (2), 1028-1043.

Kolapo, F. T. \& Adaramola, A. O. (2012). The Impact of the Nigerian Capital Market on Economic Growth (19902010). International Journal of Developing Societies. 1(1), 11-19

Kurihara, Y. (2006). The Relationship between Exchange Rate and Stock Prices during the Quantitative Easing Policy in Japan. International Journal of Business. 11(4).

Kutty, G. (2010). The Relationship between Exchange Rates and Stock Prices: The Case of Mexico. North American Journal of Finance and Banking Research. 4 (4), 1-9

Lawal, M. \& Ijirshar, U. V. (2015). Empirical Analysis of Exchange Rate and Nigerian Stock Market Performance. International Journal of Science and Research. 4(4), 1592-1600

Mayowa, A. (2013). The Determinants of Real Exchange Rate Volatility in Nigeria. Academic Journal of Interdisciplinary Studies. 2(1), 459-471.

Narayan, P. K. (2004). Reformulating Critical Values for the Bounds F-statistics Approach to Co-integration: An Application to the Tourism Demand Model for Fiji. Discussion Paper No. 02/04, Department of Economics, Monash University, Victoria 3800, Australia.

Nigeria Stock Exchange (2014) Annual Reports and Account.

Nwakanma, C.,Ajibola, A. \& Nwakanma, H.C. (2014). Effect of Episodic Market Conditions in Beta Variability in Nigerian Stock Market. International Journal of Business and Economic Research. 13 (2).

Okpara, G. C. \& Odionye, J. C. (2012). Analysis of the Relationship between Exchange Rates and Stock Prices: Evidence from Nigeria. Interntional Journal of Current Research. 4(3), 175-183

Olanipekun, D. B. (2013). Exchange Rate Volatility and Economic Activities in Nigeria. A Ph.D Post Field Report. Department of Economics, University of Ibadan, 1-41

Olugbenga, A. A. (2012). Exchange Rate Volatility and Stock Market Behaviour: The Nigerian Experience. European Journal of Business and Management. 4(5), 31-40

Osahon, O.H. (2014). Measuring Nigerian Stock Market Volatility. Singaporean Journal of Business Economics and Management Studies. 2 (8).

Osamwonyi, I.O. \& Kasimu, A. (2013). Stock Market and economic Growth in Ghana, Kenya and Nigeria. International Journal of Financial Research. 4 (2), 83-98.

Osamwonyi, I. O. \& Evbayiro-Osagie, E. I. (2012). The Relationship between Macroeconomic Variables and Stock Market Index in Nigeria. Journal of Economics. 3(1), 55-63

Pesaran, M.H., Y. Shin., \& Smith R. (2001) Bounds Testing Approaches to the Analysis of Level Relationships, Journal of Applied Econometrics, 16, 289-326.

Qqyyum, A \& Khan, M.A. (2012). Dynamic Relationship and Volatility Spillover between the Stock Market and the Foreign Exchange Market in Pakistan: Evidence from VAR-GARCH Modelling.

Securities and Exchange Commission, (2013). Capital Market Bulletin. 1(5), 13-23.

Umoru, D. \& Asekoma, M.O. (2013). Stock Prices and Exchange Rate Variability in Nigeria: Econometric Analysis of the Evidence. European Scientific Journal. 9 (25), 261 - 285.

Usman, O. A. \& Adegbite, A. T. (2013). Effect of Exchange Rate Volatility on Nigeria Economy (1991-2010).

International Journal of Academic Research in Economics and Management Sciences. 2(6), 172-184 
Wang, K. \& Christopher, B. (2007). Estimating the Effect of Exchange Rate Volatility on Export Volumes. Journal of Agricultural and Resource Economics. 22, 225-255.

World Development Indicators, (2015). World Bank Database for Development Data.

Zubair, A. (2013). Causal Relationship between Stock Market Index and Exchange Rate: Evidence from Nigeria. C.B.N. Journal of Applied Statistics. 4 (2). 